\title{
First record of death-feigning in Black Vultures (Coragyps atratus) (Cathartidae)
}

\author{
Marjory Auad Spina ${ }^{1,2,3} \&$ Luís Fábio Silveira ${ }^{1,2}$ \\ Programa de Pós-Graduação em Conservaçáo da Fauna, Centro de Ciências Biológicas e da Saúde, Universidade Federal de São Carlos - UFSCar, \\ São Carlos, SP, Brazil. \\ 2 Seção de Aves, Museu de Zoologia da Universidade de São Paulo - MZUSP, São Paulo, SP, Brazil. \\ 3 Corresponding author: marjoryspina@gmail.com
}

Received on 23 June 2019. Accepted on 18 November 2019.

\begin{abstract}
Death-feigning is a behavior ability with the purpose of allowing prey to evade from predators. Despite death-feigning is recorded on a wide variety of bird species, it has been recorded only once in vultures, more specifically on a Turkey Vulture (Cathartes aura) nest. In addition to this record, we report this behavior while manipulating an individual of Black Vulture (Coragyps atratus) in Brazil. This behavior is not usual in Cathartidae since adult vultures do not have a known natural predator.
\end{abstract}

KEY-WORDS: anti-predator behavior, Brazil, physical contact, thanatosis.

Although Black Vultures (Coragyps atratus) are considered gregarious and group-forming species that can reach hundreds of individuals that feed, soar and roost together, they do not breed in colonies. They are not territorialists and fly large areas in search of food and shelter, considered rapid colonists, mainly in newly-opened anthropic-formed areas. Since individuals fly widely, they are considered as partially migratory birds, keeping longer periods of time in areas where a higher amount of resources is available (Mundy 1985, Souto 2008, Ribeiro et al. 2010). On the other hand, they have a strong agonistic behavior when it comes to a resource dispute, due to food competition. Among age-groups there are different behavioral features, such as juveniles being more submissive to the elders, as reported by Kruuk (1967), Houston (1975) and Ribeiro et al. (2010).

Aggregation in American Black Vultures brings about advantages, such as increased social interactions. Individuals may also benefit by being close to one another, mainly through thermoregulation mechanisms by using communal perches in trees, rocks or urban infrastructure (Campbell 2015, Ballejo 2016).

Thanatosis (or death-feigning) frequently occurs in response to the presence of predators, generating a state of immobility by the prey (Miyatake et al. 2004, Humphreys $\&$ Ruxton 2018). Although thanatosis has been described in many groups, such as mammals, birds, fish, reptiles, amphibians, arachnids and insects (Miyatake et al. 2004, Humphreys \& Ruxton 2018), it is more frequently found in prey than predators, like vultures. Few studies have reported thanatosis in predators, for example, Vogel-Jr. (1950) recorded thanatosis in a wild adult Turkey Vulture (Cathartes aura) in Indiana, USA, when the vulture was nesting in a Sycamore Tree, with two white downy chicks. Due to the human presence looking at the nest, the adult remained completely motionless, remaining in a prone position with its wings opened and its head down. Although it had been prodded with a stick and lifted off the ground, one could only notice eye movements (Vogel-Jr. 1950). On another occasion, Martin-Jurado et al. (2011) reported thanatosis in an adult individual of Red Kite (Milvus milvus) after anesthesia for a surgical procedure aiming for sex determination. This behavior was confirmed through the bispectral index, which evaluates the electrical activity of the brain of the bird. After finishing the surgery, followed by extubation, the Red Kite remained immobile and unresponsive, despite the bispectral index corresponded to a full awake bird.

In this report, we characterized thanatosis in one Black Vulture individual, recorded in 2018 during the removal from a handling-net (Fig. 1).

The individual was captured at the Fundação Parque Zoológico de São Paulo. The survey comprised biological sample collections such as feces, regurgitates as well as any ectoparasite encountered during the procedure. This individual was captured, quickly pulled out of the trap with a handling net and immediately released afterward. However, when released, the Black Vulture remained lying in the dorsal position. We could even lift the individual off the ground by holding it only by its legs. 


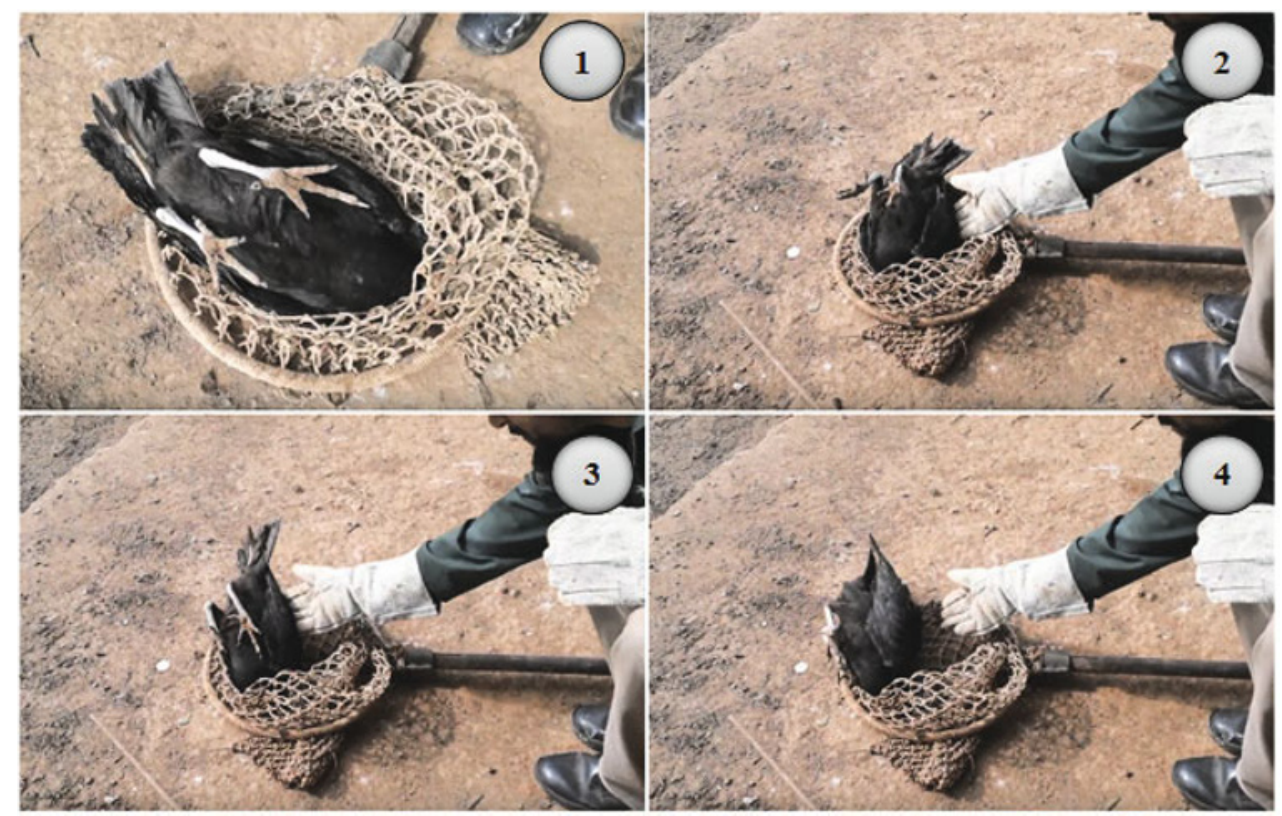

Figure 1. Picture description showing thanatosis in a Black Vulture captured at the Fundação Parque Zoológico de São Paulo. (1) Individual lying down in dorsal decubitus; (2) touched without showing any response; (3) pushed out of the handling net without showing any response; (4) sideway-fallen Black Vulture seconds before rising.

After realizing that either it was expressing thanatosis or having a health issue, we placed the individual back on the handling net, in which it remained for a few seconds and it stood and flew away.

Thanatosis is an anti-predatory strategy frequently adopted by prey after physical contact by predator (Humphreys \& Ruxton 2018). However, such behavior is uncertain in this particular situation described here. Even though vultures are vulnerable to predation by terrestrial carnivores when they are fledglings and juveniles, few reports of adults being predated are known (Houston 1994, Teixeira et al. 2019). In spite of being quite common in several taxa, the adaptive significance of thanatosis is still uncertain. Lack of studies may be attributed to the fact that the usual consequence of thanatosis may be predation, being less likely to be seen or tested in the field and laboratory due to ethical reasons. Besides that, the success or failure of death feigning depends largely on the foraging techniques adopted by the predator. More studies are needed with regards to the predator-prey dynamics of vultures, in order to fully understand the predator-avoidance tactics involved within this species (Honma et al. 2006, Humphreys \& Ruxton 2018).

\section{ACKNOWLEDGEMENTS}

We thank Fundação Parque Zoológico de São Paulo for the grant and support, Universidade Federal de São Carlos, Animal Ethics Committee (CEUA-UFSCar) and Instituto Chico Mendes de Conservação da Biodiversidade (ICMBio) for the licenses. We also thank Eli Carlos dos Santos for helping with the capture of the Black Vultures and to an anonymous reviewer that contributed to improve the manuscript.

\section{REFERENCES}

Ballejo F. 2016. Ecología trófica y tafonomía del Jote de Cabeza Negra, Coragyps atratus (Cathartidae) y su comparación con otros Cathartidae en el noroeste de la Patagonia. Ph.D. Thesis. La Plata: Facultad de Ciencias Naturales y Museo, Universidad Nacional de La Plata.

Campbell M.O. 2015. Systematic list of New World vultures, p. 71112. In: Campbell M.O. (ed.). Vultures: their evolution, ecology and conservation. Boca Raton: CRC Press.

Honma A., Oku S. \& Nishida T. 2006. Adaptive significance of death feigning posture as a specialized inducible defence against gapelimited predators. Proceedings of the Royal Society of London B: Biological Sciences 273: 1631-1636.

Houston D. 1975. Ecological isolation of African scavenging birds. Ardea 63: 55-64.

Houston D.C. 1994. Family Cathartidae (New World vultures), p. 24-41. In: del Hoyo J., Elliot A. \& Sargatal J. (eds.). Handbook of the birds of the world, v. 2 (New World vultures to guineafowl). Barcelona: Lynx Editions.

Humphreys R.K. \& Ruxton G.D. 2018. A review of thanatosis (death feigning) as an anti-predator behaviour. Behavioral Ecology and Sociobiology 72: 22.

Kruuk H. 1967. Competition for food between vultures in east Africa. Ardea 55: 171-193.

Martin-Jurado O., Simova-Curd S., Bettschart-Wolfensberger R. \& Hatt J.-M. 2011. Bispectral index reveals death-feigning behavior in a Red Kite (Milvus milvus). Journal of Avian Medicine and Surgery 25: 132-135.

Miyatake T., Katayama K., Takeda Y., Nakashima A., Sugita A. \& Mizumoto M. 2004. Is death-feigning adaptative? Heritable variation in fitness difference of death-feigning behaviour. 
Proceedings of the Royal Society of London B: Biological Sciences 271: 2293-2296.

Mundy P.J. 1985. The biology of vultures: a summary of the workshop proceedings. ICBP Technical Publication 5: 457-482.

Ribeiro L.B., Lima D.G. \& Melo S.B.F. 2010. Interação competitiva de Coragyps atratus (Bechstein, 1793) (Cathartiformes, Cathartidae) no uso de um recurso limitado. Revista de Etologia 9: 34-39.

Souto H.N. 2008. Ecologia de interaçôes entre Coragyps atratus (Bechstein, 1793) e Caracara plancus (Miller, JF, 1777) no município de Uberlândia (MG). M.Sc. Dissertation. Uberlândia: Universidade Federal de Uberlândia.

Teixeira F.D., Mesquita E.P., Ferreira M.A. \& Araújo F.C. 2019. Diet of Ornate Hawk-Eagle (Spizaetus ornatus). Revista Brasileira de Ornitologia 27: 31-39.

Vogel-Jr. H.H. 1950. Observations on social behavior in Turkey Vultures. Auk 67: 210-216.

Associate Editor: Lilian T. Manica. 